\title{
ANALISIS KEMAMPUAN KOGNITIF PADA LANGKAH-LANGKAH PEMECAHAN MASALAH DITINJAU DARI KECERDASAN LOGIS- MATEMATIS
}

\author{
Rakha Pradestya ${ }^{1}$, Aritsya Imswatama ${ }^{2}$, Pujia Siti Balkist ${ }^{3}$ \\ 1,2,3 Universitas Muhammadiyah Sukabumi \\ rpradestya@gmail.com \\ iaritsya@gmail.com \\ pujiabalkist@ummi.ac.id
}

\begin{abstract}
ABSTRAK
Penelitian ini dilakukan untuk menganalisis kemampuan kognitif siswa pada langkah-langkah pemecahan masalah ditinjau dari kecerdasan logis-matematis pada materi Sistem Persamaan Linear Dua Variabel. Penelitian ini dilakukan dengan metode kualitatif jenis studi kasus. Subjek penelitian adalah kelas VIII di SMP Khalifah Boarding School yang berjumlah 17 siswa. Tahap pertama penelitian ini adalah pengambilan data yang dilakukan sebanyak dua kali, yaitu menggunakan instrumen angket kecerdasan logis-matematis yang bertujuan untuk menggambarkan pemetaan kecerdasan logismatematis siswa yang nantinya akan dipilih tiga orang sebagai subjek penelitian dengan tingkatan kecerdasan logis-matematis yang berbeda. Hasil penelitian ini menunjukkan bahwa: (1) siswa yang memiliki kecerdasan logis-matematis tinggi memiliki kemampuan kognitif yang baik pada tingkatan mengingat, memahami, menerapkan, menganalisis, dan mengevaluasi. (2) Siswa dengan tingkat kecerdasan logis matematis sedang tidak bisa dikatakan memiliki kemampuan kognitif yang cukup, bahkan masih terbilang rendah, karena siswa tersebut masih belum dikatakan baik pada kemampuan kognitif menerapkan. Hal ini dikarenakan siswa tidak bisa menerapkan konsep atau rumus yang diingat dengan baik sehingga nilai yang didapatkan tidak tepat. (3) Siswa dengan tingkat kecerdasan logis matematis rendah memiliki kemampuan kognitif yang rendah. Hal ini dikarenakan siswa tersebut tidak sampai pada tahap memahami. (4) Kecerdasan logis-matematis tidak berbanding lurus dengan kemampuan kognitif. (5) Faktor penyebab rendahnya kemampuan kognitif siswa adalah sebagai berikut: (a) Kurangnya pemahaman tentang materi yang diterapkan pada tes, (b) Lemahnya keterampilan dalam memperoleh informasi dari soal, (c) Kurang teliti dalam pemecahan masalah, (d) Pesimis dan kurang percaya diri.
\end{abstract}

Kata Kunci: Kognitif, pemecahan masalah, logis-matematis, Sistem Persamaan Linear Dua Variabel

\begin{abstract}
This study is done to analysing the student's cognitive abilities in problem solving steps examined for logic-mathematical intelligence in the system of linear equations in two variables. This is a qualitative study in kind of case studies. Subject were 17 students of VIII grader in the SMP Khalifah Boarding school. It's using various stages in the application. First is date retrieval intended to illustrate the mapping of the logic-mathematical intelligence of student that three would later choose subject of study of a different level of logic-mathematical intelligence. The results show that: (1) students with high logic-mathematical intelligence have good cognitive ability on memory levels understand, apply, analyse, and evaluate. (2) the student with a level of mathematical intelligence is not to be said to have sufficient cognitive ability. This in because student cannot apply well remembered concepts or formulas that have inappropriate value (3) students with a low level mathematical logical intelligence have log cognitive abilities. (4) Logical mathematical intelligence is not directly proportional to cognitive abilities 1. This is evident because student with moderate but logical mathematical intelligence is not inversely
\end{abstract}


proportional to cognitive ability, because student with high logical mathematical intelligence have high cognitive abilities as well. (5) factors that cause the low cognitive abilities of students are as follows: a. Lack of understanding of the material applied to the test b. Weak skill in obtaining information from questions c. Less careful in problem solving d. Pessimistic and lack of confidence.

Keywords: Cognitive; problem solving, logic-mathematic, system of linear equations in two variables

\section{PENDAHULUAN}

Ide kajian teori ini muncul dari fenomena di sekolah tentang langkah-langkah pemecahan masalah dan kemampuan kognitif dari masing-masing siswa, khususnya di SMP Khalifah Boarding School. Setiap siswa memiliki proses pemecahan masalah yang berbeda satu sama lain dan menghadapi kesulitan yang berbeda-beda. Kesulitan yang dihadapi oleh siswa bergantung pada kemampuan kognitif yang dimiliki.

Kemampuan kognitif adalah kemampuan siswa dalam proses berpikir dan kemampuan pemecahan masalah. Menurut Huda (Susanti, 2018) kualitas pendidikan yang baik diperoleh dengan menerapkan semua tingkat ranah kognitif dalam setiap pembelajaran. Taksonomi Bloom ranah kognitif yang telah direvisi (Anderson, 2001) yakni: mengingat (remember), memahami/mengerti (understand), menerapkan (apply), menganalisis (analyse), mengevaluasi (evaluate), dan menciptakan (create). Berikut adalah karakteristik kemampuan kognitif siswa:

Kesulitan yang dialami oleh masing-masing siswa tidak terlepas dari seberapa baiknya kemampuan kognitif siswa. Siswa mengalami kesulitan ketika siswa tersebut belum mencapai tingkatan kemampuan kognitif di atas. Hal ini dapat dilihat dari bagaimana siswa memecahkan masalah dengan memanfaatkan kemampuan kognitif yang dimiliki.

Pemecahan masalah merupakan satu strategi kognitif yang diperlukan dalam kehidupan sehari-hari. Berpikir mengenai pemecahan masalah dapat membantu dalam dua alasan. Pertama, penekanan kesinambungan proses pemecahan masalah dengan cara kita bergerak dari keadaan awal hingga keadaan akhir dapat dirumuskan secara lebih jelas. Kedua, berpikir mengenai pemecahan masalah merupakan salah satu proses perubahan dari satu keadaan pada keadaan lain yang dapat meningkatkan pemahaman. Masalah yang dihadapi dapat dipecahkan dengan menggunakan strategi yang bersifat umum.

Pemecahan masalah terhadap suatu masalah bisa jadi berbeda setiap siswa, karena kemampuan kognitif masing-masing siswa berbeda. Hal ini bergantung pada seberapa banyak struktur pengetahuan yang dimiliki oleh masing-masing siswa. Terdapat rumusan masalah yang 
"ill-defined problem" yaitu yang memiliki lebih dari satu solusi dan tidak bersifat universal. Adapula yang "well-defined problem" yaitu hanya memiliki satu solusi dan bersifat universal.

Pemecahan masalah adalah kegiatan yang bertujuan untuk mencari solusi dari suatu permasalahan. Polya menyatakan bahwa pemecahan masalah adalah salah satu aspek berpikir tingkat tinggi. Sehingga Polya (Hartono, 2014: 2) mengemukakan dua macam masalah matematika yaitu : (1) Masalah untuk menemukan (problem to find) dimana kita mencoba untuk mengkonstruksi semua jenis objek atau informasi yang dapat digunakan untuk menyelesaikan masalah tersebut, dan (2) Masalah untuk membuktikan (problem to prove) dimana kita akan menunjukkan salah satu kebenaran pernyataan, yakni pernyataan itu benar atau salah. Masalah jenis ini mengutamakan hipotesis ataupun konklusi dari suatu teorema yang kebenarannya harus dibuktikan.

Hubungan antara langkah-langkah pemecahan masalah dan kemampuan kognitif bisa dilihat pada tabel berikut:

Tabel 1. Indikator Kemampuan Kognitif pada Langkah-Langkah Pemecahan Masalah menurut Polya.

\begin{tabular}{ll}
\hline \multicolumn{1}{c}{ Pemecahan Masalah } & Kemampuan Kognitif \\
\hline \multirow{2}{*}{ Memahami masalah } & Mengingat \\
& Memahami \\
\hline Perencanaan pemecahan masalah & Penerapan \\
\hline \multirow{2}{*}{ Memecahkan masalah sesuai rencana } & Menganalisis \\
& Mengevaluasi \\
\hline Melihat kembali pemecahan masalah & Mencipta \\
\hline
\end{tabular}

Kecerdasan logis-matematis adalah peraduan antara kemampuan berhitung dan kemampuan berpikir logis. Kecerdasan logis-matematis juga dapat diartikan sebagai kemampuan siswa dalam menghitung, mengukur, menganalisis, atau melakukan hal-hal lain yang berkaitan dengan matematika. Dalam kemampuan ini terdapat komponen-komponen, yaitu berpikir logis, pemecahan masalah, ketajaman membaca pola atau hubungan dari sebuah masalah, konsep kuantitas, induktif-deduktif, dan hubungan sebab akibat.

\section{METODE PENELITIAN}

Kualitatif jenis studi kasus untuk mengetahui kemampuan kognitif siswa pada langkahlangkah pemecahan masalah ditinjau dari kecerdasan logis-matematis. Arifin (Susanti, 2018) menyatakan bahwa penelitian studi kasus merupakan penelitian yang mendalam tentang 
individu, satu kelompok, satu organisasi, satu program kegiatan dalam waktu tertentu. Tujuannya untuk memperoleh deskripsi yang utuh dan mendalam. Mendalam, artinya mengungkap dan menggali data secara mendalam dan faktor-faktor yang dapat menyebabkan terjadinya kasus tersebut. Data studi kasus diperoleh dari wawancara dan tes tertulis

Instrumen yang digunakan pada penelitian ini terlebih dahulu dilakukan validasi kepada validator ahli. Instrumen terdiri dari angket kecerdasan logis-matematis dan tes pemecahan masalah. Subjek penelitian diambil menggunakan angket kecerdasan logis-matematis. Angket diberikan 17 siswa kelas VIII SMP Khalifah Boarding School. Berdasarkan hasil perolehan skor siswa pada angket tersebut, dipilih tiga subjek penelitian yaitu satu siswa dengan kecerdasan logis-matematis tinggi, satu siswa dengan kecerdasan logis-matematis sedang, dan satu siswa dengan kecerdasan logis-matematis rendah. Setelah subjek ditentukan, subjek diberi tes pemecahan masalah yang berisikan tiga soal tentang Sistem Persamaan Linear Dua Variabel untuk mendapatkan data dari kemampuan kognitif dari masing-masing subjek penelitian. Setelah diberikan tes, jawaban dari subjek penelitian dianalisis terlebih dahulu, lalu dilakukannya wawancara. Data yang diperoleh kemudian divalidasi menggunakan triangulasi data, dengan membandingkan jawaban siswa dan hasil wawancara, sehingga dapat ditarik kesimpulan.

\section{HASIL DAN PEMBAHASAN}

Data awal adalah data dari perolehan skor angket. Data ini menunjukkan didapat tiga subjek penelitian dengan perolehan skor dari subjek penelitian:

Tabel 2. Perolehan Skor Angket Kecerdasan Logis-Matematis Subjek Penelitian

\begin{tabular}{ccc}
\hline Subjek & $\begin{array}{c}\text { Kecerdasan Logis- } \\
\text { Matematis }\end{array}$ & Skor \\
\hline ATDP (Subjek 1) & Tinggi & 22 \\
RAF (Subjek 2) & Sedang & 19 \\
AAK (Subjek 3) & Rendah & 13 \\
\hline
\end{tabular}

Subjek penelitian diberikan tes pemecahan masalah. Soal pertama pada tes ini adalah "Di sebuah keluarga, terdapat dua bersaudara, yaitu Khresna dan Rakha. 3 tahun lalu, usia Khresna adalah 2 kali usia Rakha. Enam tahun yang akan datang, selisih keduanya adalah 3. Berapakah jumlah usia Khresna dan Rakha 10 tahun yang akan datang?”. Soal kedua adalah "Diketahui sebuah persegi panjang dengan panjang $\mathrm{p}$ dan lebarnya adalah sepertiga dari $\mathrm{p}$ 
ditambah 4. Jika keliling persegi panjang adalah $32 \mathrm{~cm}$. Tentukan luasnya!”. Soal ketiga adalah "SMP Khalifah Boarding School diberikan bantuan oleh Jepang bernama OISCA (Organization for Industrial and Cultural Advancement) untuk mengadakan pembudidayaan lingkungan berupa bibit tanaman tertentu. Diberdayakanlah dua tempat untuk kegiatan tersebut dengan masing-masing tempat memiliki luas lahan yang berbeda. Penanaman bibit dilakukan dalam dua tahap di kedua tempat tersebut sebagaimana pada tabel berikut:

Tabel 3. Soal nomor 3

\begin{tabular}{llll}
\hline Tahap & Lahan 1 & Lahan 2 & Biaya \\
\hline 1 & 300 bibit & 200 bibit & Rp 540.000,00 \\
2 & 320 bibit & 250 bibit & Rp 620.000,00 \\
\hline
\end{tabular}

Jika biaya pada masing-masing tahap tetap, berapakah biaya yang diperlukan jika Desty ingin menanam 315 bibit di lahan 1 dan 225 bibit di lahan 2?".

Data penelitian hasil analisis jawaban subjek adalah sebagai berikut.

Tabel 4. Klasifikasi Hasil Analisis Jawaban Subjek pada Soal Nomor 1

\begin{tabular}{llcccc}
\hline \multirow{2}{*}{ Langkah Pemecahan Masalah } & Kemampuan & \multicolumn{3}{c}{ Subjek Penelitian } \\
\cline { 3 - 6 } & Kognitif & S1 & S2 & S3 \\
\hline Memahami masalah & Mengingat & $\mathrm{T}$ & $\mathrm{T}$ & $\mathrm{R}$ \\
Perencanaan pemecahan masalah & Memahami & $\mathrm{T}$ & $\mathrm{S}$ & $\mathrm{R}$ \\
Menerapkan pemecahan masalah & Menerapkan & $\mathrm{T}$ & $\mathrm{S}$ & $\mathrm{R}$ \\
& Menganalisis & $\mathrm{T}$ & $\mathrm{R}$ & $\mathrm{R}$ \\
Melihat kembali pemecahan masalah & Mengevaluasi & $\mathrm{T}$ & $\mathrm{R}$ & $\mathrm{R}$ \\
& Mencipta & $\mathrm{R}$ & $\mathrm{R}$ & $\mathrm{R}$ \\
\hline
\end{tabular}

Tabel 5. Klasifikasi Hasil Analisis Jawaban Subjek pada Soal Nomor 2

\begin{tabular}{llcccc}
\hline \multirow{2}{*}{ Langkah Pemecahan Masalah } & Kemampuan & \multicolumn{3}{c}{ Subjek Penelitian } \\
\cline { 3 - 5 } & Kengingat & S1 & S2 & S3 \\
\hline Memahami masalah & Memahami & $\mathrm{T}$ & $\mathrm{T}$ & $\mathrm{S}$ \\
& Menerapkan & $\mathrm{T}$ & $\mathrm{T}$ & $\mathrm{R}$ \\
Perencanaan pemecahan masalah & Menganalisis & $\mathrm{T}$ & $\mathrm{R}$ \\
Menerapkan pemecahan masalah & Mengevaluasi & $\mathrm{T}$ & $\mathrm{R}$ \\
& Mencipta & $\mathrm{R}$ & $\mathrm{R}$ & $\mathrm{R}$ \\
\hline
\end{tabular}

Tabel 6. Klasifikasi Hasil Analisis Jawaban Subjek pada Soal Nomor 3

\begin{tabular}{llcccc}
\hline \multirow{2}{*}{ Langkah Pemecahan Masalah } & Kemampuan & \multicolumn{3}{c}{ Subjek Penelitian } \\
\cline { 3 - 6 } & Kognitif & S1 & S2 & S3 \\
\hline Memahami masalah & Mengingat & T & T & R \\
& Memahami & T & S & R \\
Perencanaan pemecahan masalah & Menerapkan & $\mathrm{T}$ & S & R \\
Menerapkan pemecahan masalah & Menganalisis & $\mathrm{T}$ & $\mathrm{S}$ & $\mathrm{R}$ \\
& Mengevaluasi & $\mathrm{R}$ & $\mathrm{R}$ & $\mathrm{R}$ \\
Melihat kembali pemecahan masalah & Mencipta & $\mathrm{R}$ & $\mathrm{R}$ & $\mathrm{R}$ \\
\hline
\end{tabular}

Keterangan: $T=$ tinggi, $S=$ sedang, $R=$ rendah 
Data penelitian di atas didukung oleh hasil wawancara kepada setiap subjek yang bertujuan untuk mendapatkan informasi terkait kesulitan subjek dalam memecahkan tes yang diberikan. Berikut adalah hasil triangulasi data jawaban subjek dengan wawancara dari masingmasing subjek.

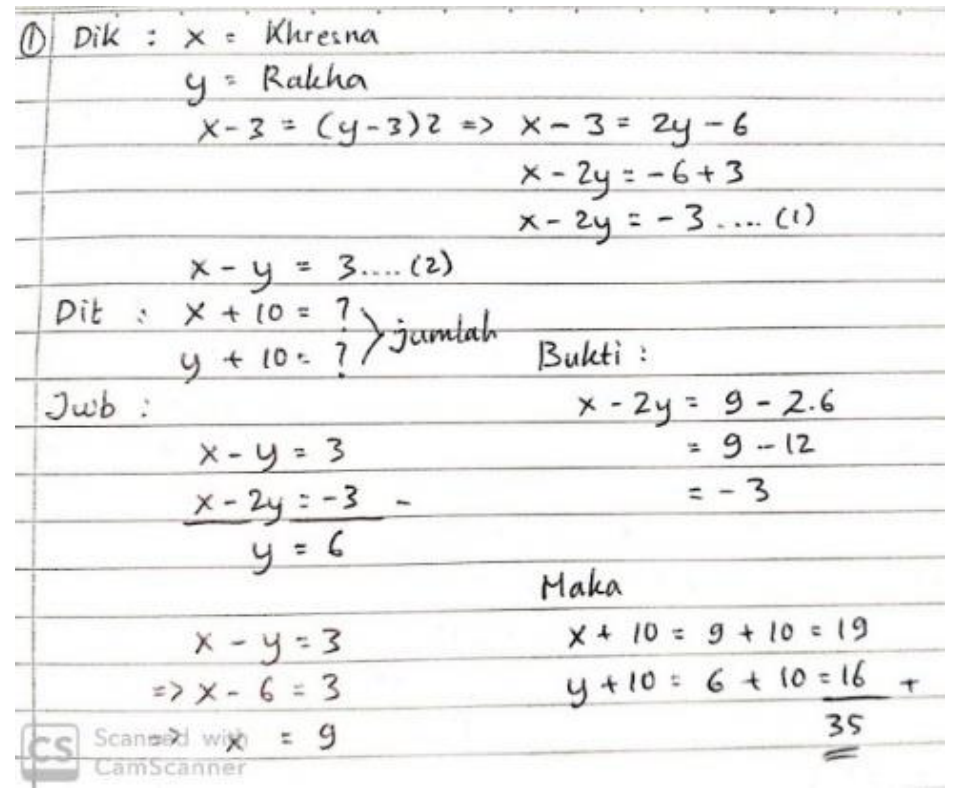

Gambar 1. Jawaban Nomor 1 dari Subjek 1

Gambar di atas adalah gambar jawaban Subjek 1 terhadap soal nomor 1. Adapun wawancara yang dilakukan terkait dengan jawaban yang diberikan sebagai berikut:

P : "Coba lihat ini! Perhatiin nomor 1 nih. Yang diketahuinya apa aja ya? Ini ya? (sambil nunjuk yang diketahui). Kenapa ini bisa jadi $\mathrm{x}-2 \mathrm{y}=-3$ ?"

S1 : "Hmmmm, jadi dari keterangan "3 tahun lalu, usia Khresna dua kali usia Rakha". Nah dari situ kan misal Khresna $=\mathrm{x}$ dan Rakha $=\mathrm{y}$. Jadi dapet $\mathrm{x}-3=(\mathrm{y}-3) 2$, diotak-atik dapet aja $x-2 y=-3$. Dan yang selisih, karena selisih ga akan berubah, jadi $x-y=3$ "

P : "Kalo yang ditanyakannya?"

S1 : "Yang tertera, ditanyakannya itu $(x+10)+(y+10)$ "

P : “Apa itu?"

S1 : "Jumlah usia Mereka 10 tahun ke depan"

Berdasarkan data di atas, dapat disimpulkan bahwa Subjek 1 sudah mahir dalam mencari informasi yang terdapat pada soal. Subjek juga sudah mahir dalam menggunakan konsep dan rumus yang seharusnya digunakan untuk menyelesaikan soal tersebut dan jawaban yang didapatnya pun tepat serta mahir dalam menerapkannya sehingga hasil yang didapat tepat 
walaupun tidak tercipta atau menemukan konsep baru pada pemecahan masalahnya. Subjek 1 memaparkan bahwa pada pemecahan nomor 1, Subjek mengalami kesulitan ketika mengubah kalimat soal menjadi bentuk matematikanya. Hal ini didapat dari kutipan wawancara terhadap Subjek 1. Subjek 1 berkata "Kalo nomor 1 susahnya ngerubah soal ke bentuk matematikanya", walaupun pada akhirnya Subjek 1 bisa memecahkan masalah pada nomor 1 dan menghasilkan jawaban yang tepat. Maka dari itu, Subjek 1 memiliki kemampuan kognitif yang tinggi pada kemampuan mengingat, memahami, menerapkan, menganalisis, dan mengevaluasi.

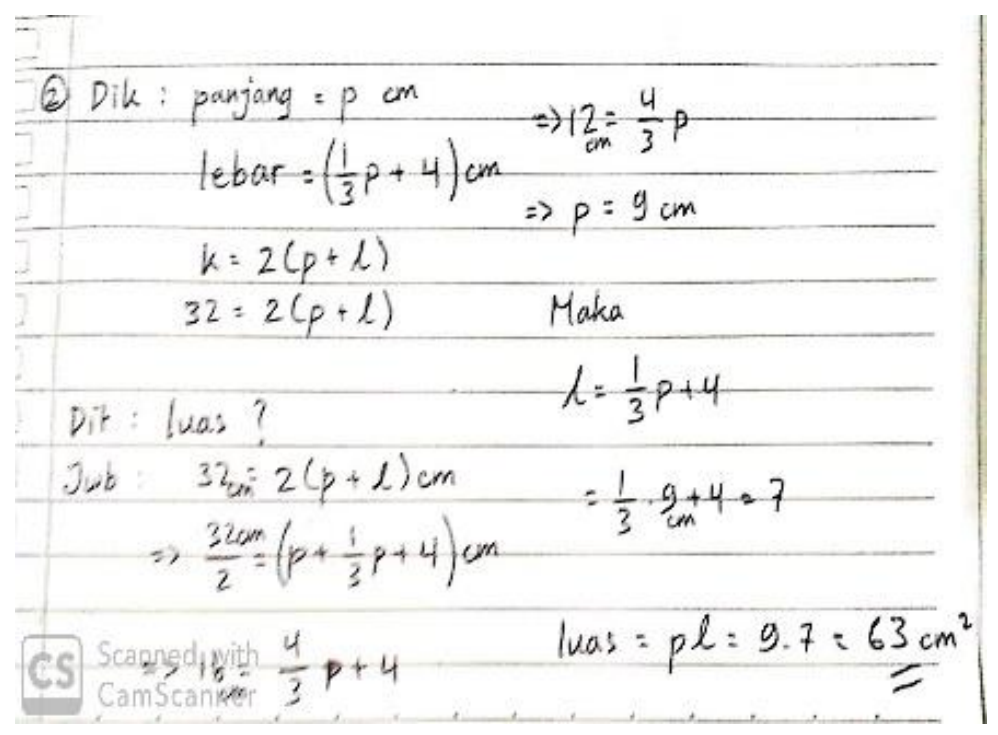

Gambar 2. Jawaban Nomor 2 dari Subjek 1

Gambar di atas adalah gambar jawaban Subjek 1 terhadap soal nomor 2. Adapun wawancara yang dilakukan terkait dengan jawaban yang diberikan sebagai berikut:

P : “....... Terus nomor 2?”

S1 : "Itu tuh Tadz yang itu (menunjuk ke penghitungan nilai p)".

P : "Oh penghitungannya ya yang $16=4 / 3 p$."

S1 : "Iya Tadz."

Berdasarkan data di atas, dapat disimpulkan bahwa subjek sudah mahir dalam mencari informasi yang terdapat pada soal. Subjek juga sudah mahir dalam menggunakan konsep dan rumus yang seharusnya digunakan untuk menyelesaikan soal tersebut dan jawaban yang didapatnya pun tepat. Subjek 1 memaparkan bahwa kesulitan dialami ketika mengoperasikan pemecahan masalah. Subjek 1 sempat terhambat ketika menghadapi persamaan $16=4 / 3 \mathrm{p}$. Namun pada akhirnya Subjek 1 bisa memecahkannya dan mendapatkan nilai $\mathrm{p}$ dengan benar sebesar 12 sehingga nilai luas yang didapat juga benar. 


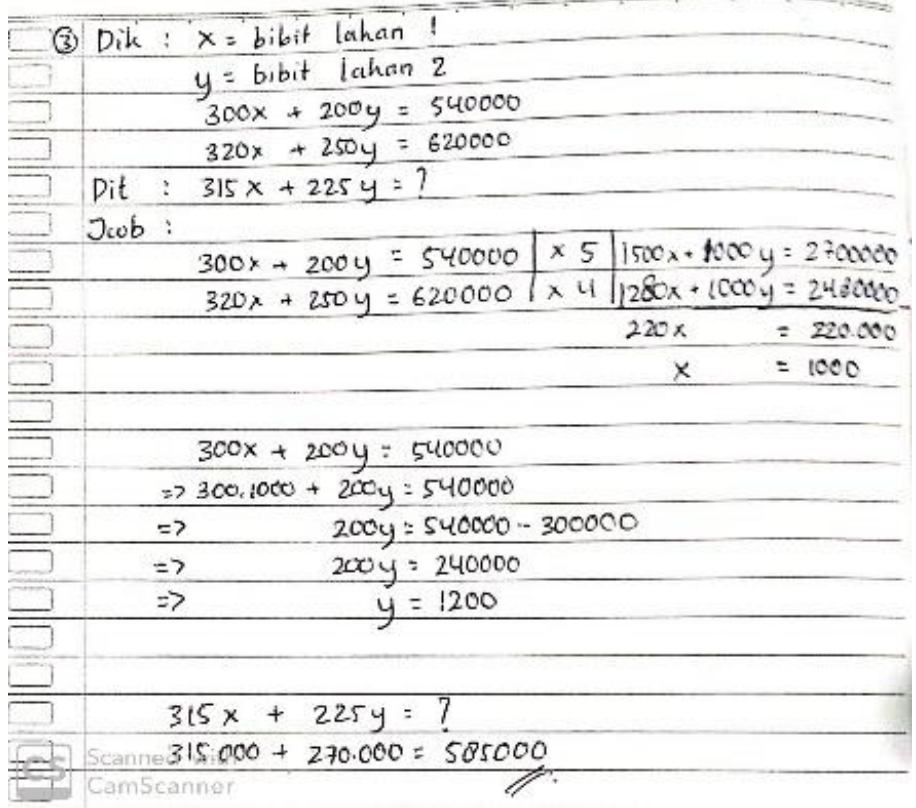

Gambar 3. Jawaban Nomor 3 dari Subjek 1

Gambar di atas adalah gambar jawaban Subjek 1 terhadap soal nomor 3. Adapun wawancara yang dilakukan terkait dengan jawaban yang diberikan sebagai berikut:

P : "Terus kalo nomor 3? Kebanyakan angka? Hahahaa"

S1 : "Iya Tadz. Ehh bukan Tadz, yang ini Tadz. Sempet kekecoh, ternyata enakan pake eliminasi dulu, baru bisa."

P : "Substitusi juga bisa. Jadi udah ya? Udah paham. Udah ga ada masalah. Jawabannya udah pada bener. Selain dari itu ga ada kesulitan lagi, ya? Jadi tadi tuh ngebentukin ke bentuk matematikanya, kedua penghitungannya, ketiga penentuan konsepnya sempet keliru, ya?”

\section{S1 : "Iya Tadz"}

Berdasarkan data di atas, dapat disimpulkan bahwa subjek sudah mahir dalam mencari informasi yang terdapat pada soal. Subjek juga sudah mahir dalam menggunakan konsep dan rumus yang seharusnya digunakan untuk menyelesaikan soal tersebut dan jawaban yang didapatnya pun tepat. Subjek 1 memaparkan bahwa kesulitan dialami ketika penerapan pemecahan masalah. Subjek 1 sempat terhambat ketika menentukan konsep mana dulu yang harus digunakan. Namun pada akhirnya Subjek 1 bisa memecahkannya dengan memanfaatkan konsep eliminasi terlebih dahulu, sehingga didapatkan nilai variabel yang benar untuk digunakan pada proses substitusi 
dalam penentuan nilai variabel lain, walaupun pada pemecahan masalah nomor 3 ini Subjek 1 tidak membuktikan terlebih dahulu kebenaran dari nilai variabel yang didapat sebelumnya.

Robert M. Gagne (Winkel, 1996) menyebutkan” pengaturan kegiatan kognitif mencakup penggunaan konsep dan kaidah yang telah dimiliki, terutama bila sedang menghadapi suatu problem.”. Berdasarkan pemaparan di atas dan pendapat dari Gagne, dapat dibuktikan bahwa Subjek 1 memiliki kemampuan kognitif yang baik karena Subjek 1 mampu memanfaatkan apa yang dimiliki atau apa yang diketahui sebelumnya sehingga masalah yang dihadapi bisa terpecahkan dengan baik.

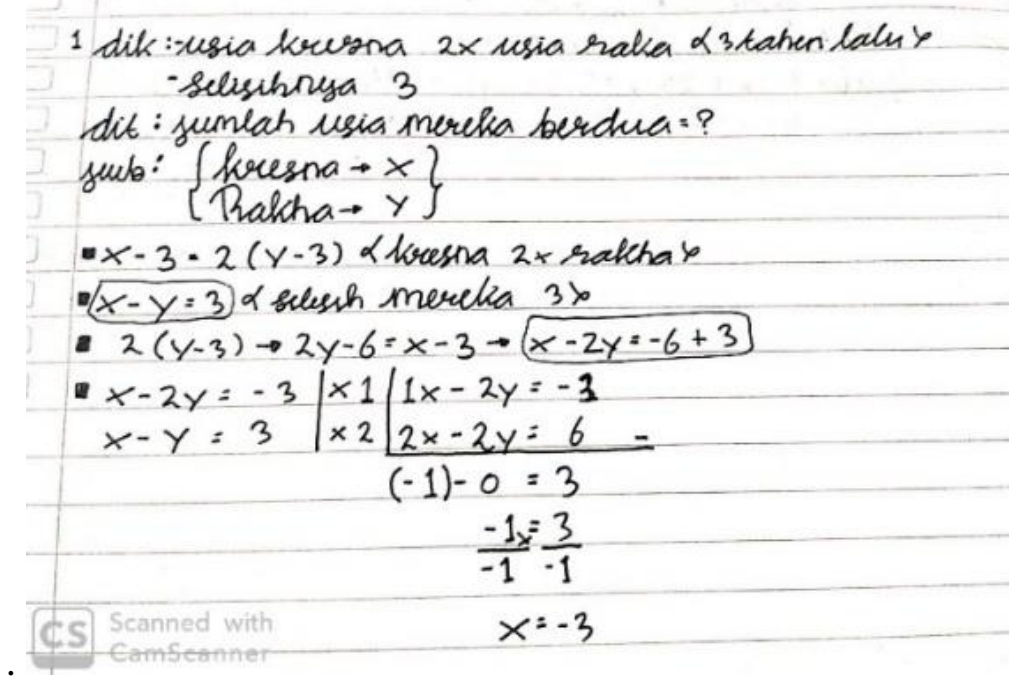

Gambar 4. Jawaban Nomor 1 dari Subjek 2

Gambar di atas adalah gambar jawaban Subjek 2 terhadap soal nomor 1. Adapun wawancara yang dilakukan terkait dengan jawaban yang diberikan sebagai berikut:

P : "Nah yang nomor 1 nih! Bingungnya di mana?"

S2 : "Nyusunnya Tadz!"

$\mathrm{P}$ : “Tapi paham pertanyaannya? Coba tulisin lagi bentuk matematikanya dari "tiga tahun lalu, usia Khresna dua kali Usia Rakha"'

S2 : "(menulis). Gini Tadz! Terus yang ditanyakan, jumlah umur."

P : "Hati-hati, ada kalimat "tiga tahun yang lalu". Ya kan?"

S2 : "Lupa Tadz!"

P: "Sebetulnya soal ini agak ngecoh. Tapi kalo udah dapet intinya mah gampang. Buktinya jawabannya bener. Ini juga sebetulnya udah beres tuh! Tinggal penerapannya tuh tinggal ngelanjutin. Sampai hasilnya tuh sekian (menunjuk nilai 
salah satu variabel yang didapat oleh Subjek 2). Tapi tinggal beberapa langkah lagi biar kelar. ......"

S2: "Nomor 1 mah Ana (Saya) sempet lupa cara nyusunnya. Terus kekecoh sama kalimat "6 tahun yang akan datang"-lah $\neg$ gitu. Terus angka mana dulu yang mesti disimpen di depan."

P : "Berarti nyusun bentuk matematikanya masih kekecoh ya?"

S2: "Iya."

$\mathrm{P}$ : "Tapi ngitungnya mah kan kalo udah dapet yang diketahuinya mah gampang ya? Tapi kalo salah nentuin ya pasti salah ke bawahnya, namanya juga matematika. Jadi kalo yang diketahuinya salah, ya pasti jawabannya juga salah kalo ga dikoreksi dan ini pun hampir ya? ....."

Berdasarkan data di atas, dapat disimpulkan bahwa subjek sudah mahir dalam mendapatkan informasi yang diketahui. Namun pada identifikasi masalah, seringkali subjek tidak teliti. Maka dari itu, informasi yang didapat kadang kurang lengkap atau keliru. Hal ini dibuktikan oleh informasi yang didapat oleh Subjek 2 masih kurang. Pada informasi yang diketahui pada gambar di atas, Subjek 2 hanya menuliskan "usia Khresna 2x usia Rakha (3 tahun yang lalu). Informasi tersebut memang benar. Namun ada informasi lain yang tidak tercantumkan, yaitu "selisih usia Khresna dan Rakha adalah 3 tahun" walaupun Subjek menyadari hal itu dan menuliskannya pada proses pemecahan masalah. Ketidaktelitian selanjutnya adalah ketika proses penghitungan, karena nilai variabel yang didapat oleh Subjek tidak tepat dan terhenti di situ. Subjek tidak bisa memanfaatkan waktu yang telah diberikan, sehingga jawaban yang dimiliki Subjek kurang lengkap.

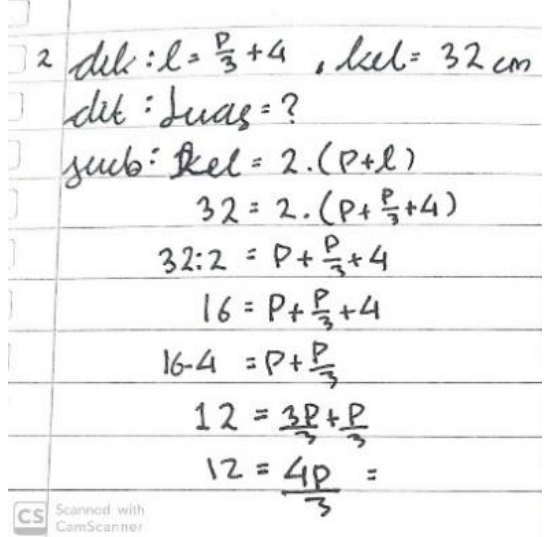

Gambar 5. Jawaban Nomor 2 dari Subjek 2 
Gambar di atas adalah gambar jawaban Subjek 2 terhadap soal nomor 2. Adapun wawancara yang dilakukan terkait dengan jawaban yang diberikan sebagai berikut:

P : "Tapi dari semua ini, paham? Terus kalo udah dapet rumusnya tinggal nerapin mah udah bisa ya?"

S2 : "Insya Allah."

P : "Cuma masih apa namanya, masih kepotong di tengah jalan keburu mentok di tengah jalan. Jadi ga tuntas jawabannya."

S2 : "Gara-gara salah rumus. Nomor 2, awalnya Ana (Saya) ingetnya 4 x sisi, padahal itu persegi. Jadi ulang lagi."

Berdasarkan data di atas, dapat disimpulkan bahwa subjek sudah mahir dalam mendapatkan informasi yang diketahui. Hal ini terbukti dari gambar di atas, terlihat Subjek 2 menuliskan informasi secara lengkap. Pada pemecahan masalah nomor 2, Subjek 2 sudah mahir dalam menerapkan konsep yang dipahami. Namun pemecahan masalah tidak tuntas. Hal ini disebabkan oleh ketidaktelitian Subjek 2 dalam menentukan konsep yang digunakan. Subjek 2 hampir saja salah menggunakan konsep. Hal ini didukung oleh kutipan wawancara berikut: "Gara-gara salah rumus. Nomor 2, awalnya Ana (Saya) ingetnya 4 x sisi, padahal itu persegi. Jadi ulang lagi.". Subjek 2 harus mengulangi proses pemecahan masalah, sehingga waktu yang dimiliki tidak cukup untuk dimanfaatkan.

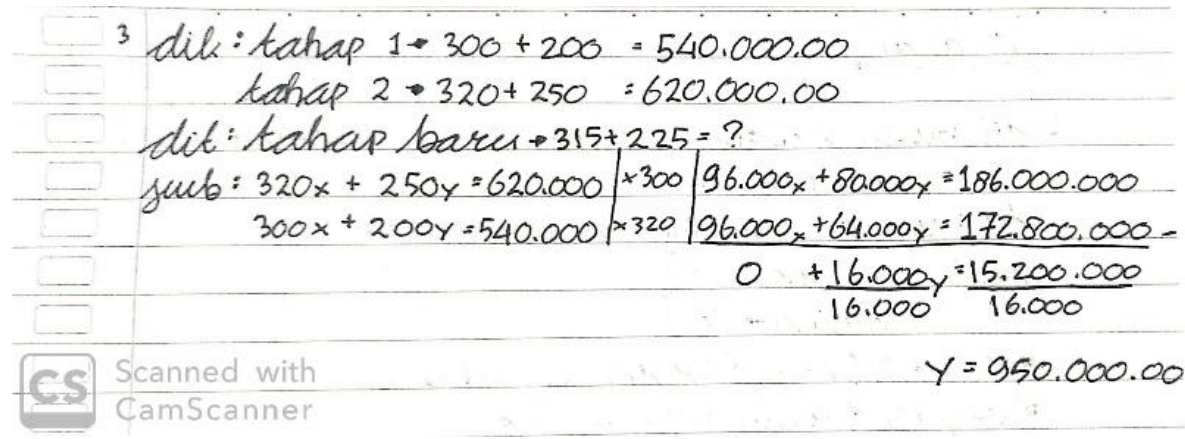

Gambar 6. Jawaban Nomor 3 dari Subjek 2

Gambar di atas adalah gambar jawaban Subjek 2 terhadap soal nomor 3. Adapun wawancara yang dilakukan terkait dengan jawaban yang diberikan sebagai berikut:

P : “.... Sekarang nomor 3. Nomor 3 paham ya? Ngebentukin ininya, ngebentukin bentuk matematikanya?"

S2 : "Iya Tadz. Tapi nomor 3 itu ngecoh banget, angkanya puluhan ratusan ribu. ....." 
P : "Berarti kurang baca soal ya? Nomor 3."

S2: "Nomor 3? Angkanya kebanyakan, lupa lanjutan. Bener terkecoh sama banyak nol Ana tuh. Padahal tinggal hilangkan dulu."

P : "Tapi dari semua ini, paham? Terus kalo udah dapet rumusnya tinggal nerapin mah udah bisa ya?"

S2 : "Insya Allah."

Berdasarkan data di atas, dapat disimpulkan bahwa subjek sudah mahir dalam mendapatkan informasi yang diketahui. Subjek sudah bisa membaca tabel dengan baik sehingga informasi yang didapatkan benar. Namun kesalahan terjadi akibat ketidaktelitian ketika proses penghitungan. Hal ini terbukti karena nilai variabel yang didapat oleh Subjek tidak tepat dan terhenti di situ. Subjek tidak fokus ketika melihat bilangan yang ada pada sal berupa bilangan ratusan ribu. Hal ini sesuai dengan pengakuan dari Subjek 2 yaitu "Iya Tadz. Tapi nomor 3 itu ngecoh banget, angkanya puluhan ratusan ribu. .....". Subjek mengalami kesulitan dalam penghitungan nilai ratusan ribu. Subjek 2 tergambar pada proses penghitungan sehingga Subjek tidak bisa memanfaatkan waktu yang telah diberikan dan jawaban yang dimiliki Subjek kurang lengkap.

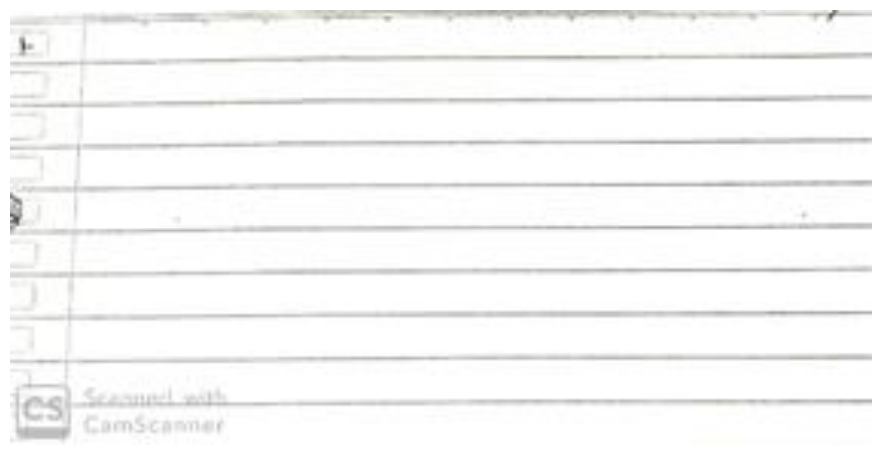

Gambar 7. Jawaban Nomor 1 dari Subjek 3

Gambar di atas adalah gambar jawaban Subjek 3 terhadap soal nomor 1. Adapun wawancara yang dilakukan terkait dengan jawaban yang diberikan sebagai berikut:

P : "Ini nih! Dilihat dari jawabannya masih pada kosong. Emang soalnya gimana sih susah atau ga ngerti? Nomor 1 deh, apa yang ga ngerti sampe ga ada catetan apapun?"

S3 : "Pas Ustadz ngejelasin materi ini, Ana (Saya) tidur Tadz. Pas bangun, udah lain lagi pembahasannya. Jadi ketinggalan. Sebetulnya kalo udah dapet mah bisa ngerjain, cuma karena ga bisa nyusunnya jadi aja ga bisa." 
P : "Oh jadi penyusunannya susah?"

S3 : "Iya Tadz."

P : "Tapi kalo dibaca lagi nih sekarang. Tolong tuliskan yang diketahuinya, dikit aja! Tiga tahun yang lalu berarti apa?"

S3 : "Dikurangi?"

P : "Betul. Berarti belum bisa baca soalnya ya? Belum bisa menuliskan apa yang diketahuinya?"

Berdasarkan data di atas, dapat disimpulkan bahwa Subjek 3 tidak mendapatkan informasi dari soal tersebut. Hal ini didapat dari gambar di atas yang menunjukkan bahwa subjek tidak menuliskan sama sekali hal yang diketahui dari soal dengan jelas. Alasannya adalah ketika pembahasan materi ini, Subjek 3 tidak menyimak, sehingga Subjek 3 tidak mengetahui cara mencari informasi dari soal tersebut. Subjek 3 tidak menuliskan informasi karena Subjek 3 tidak memahami soal tersebut.

Hasil triangulasi data menunjukkan bahwa subjek tidak bisa sama sekali mendapatkan informasi terkait apa yang diketahui dan apa yang ditanyakan, sehingga penyelesaian tidak bisa dilakukan karena kurangnya pemahaman akan soal tersebut. Subjek tidak bisa memanfaatkan waktunya sehingga tidak ada satu pun soal yang tuntas penyelesaiannya. Sebetulnya Subjek 3 paham terhadap soal dan bisa mengerjakannya. Namun Subjek 3 mengalami kesulitan dalam proses mencari informasi. Hal ini didukung oleh kutipan wawancara berikut "Pas Ustadz ngejelasin materi ini, Ana (Saya) tidur Tadz. Pas bangun, udah lain lagi pembahasannya. Jadi ketinggalan. Sebetulnya kalo udah dapet mah bisa ngerjain, cuma karena ga bisa nyusunnya jadi aja ga bisa.".

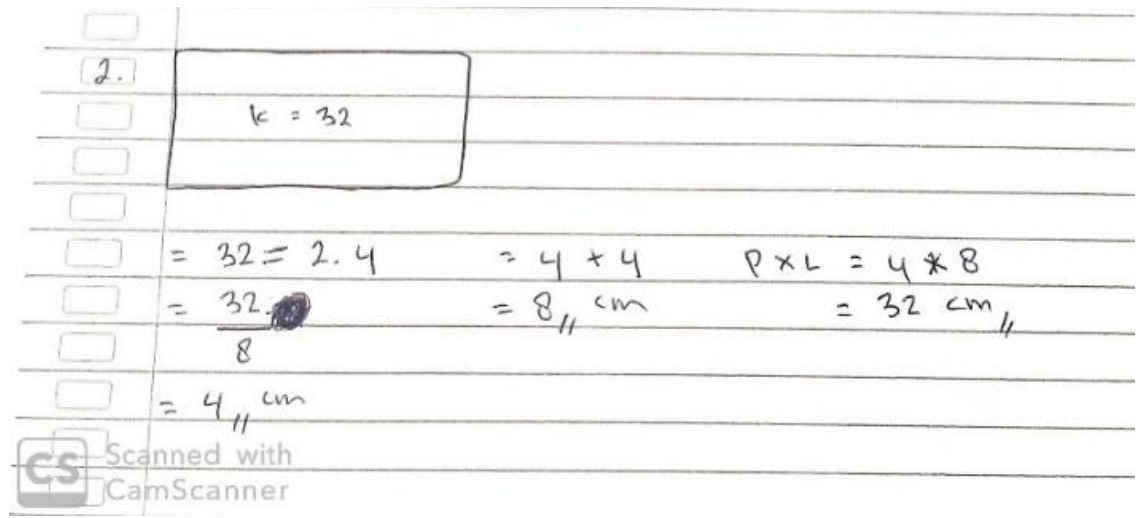

Gambar 8. Jawaban Nomor 2 dari Subjek 3 
Gambar di atas adalah gambar jawaban Subjek 3 terhadap soal nomor 2. Adapun wawancara yang dilakukan terkait dengan jawaban yang diberikan sebagai berikut:

P : “.... Lalu nomor 2 nih. Dilihat dari jawabannya udah ada nih. Yang susahnya apa? Ini dapet gini dari mana (menunjuk nilai p yang didapat)?"

S3 : "Ga tau pusing. Pokoknya kan ini 32 (keliling), terus di sini ada p ditambah 4, berarti $\mathrm{p}+4 "$

P : "Oh gitu? Tapi ini ada kalimat "sepertiga dari p" Seharusnya $1=1 / 3 p+4$. Baca soalnya masih susah ya?"

Berdasarkan data di atas, dapat disimpulkan bahwa Subjek sedikit-sedikit bisa menemukan apa yang diketahui dari soal, namun ada hal yang salah pada informasi, yaitu penentuan panjang dan lebarnya. Subjek hanya mengingat konsep luas persegi panjang, padahal pada proses ini diperlukan konsep keliling persegi panjang guna menentukan nilai $\mathrm{p}$ dan 1 yang nantinya akan digunakan untuk mencari nilai dari luas persegi panjang. Pada proses ini, Subjek 3 sudah mendapatkan informasi terkait lebar persegi di mana lebar persegi terpengaruh oleh panjang persegi karena $1=1 / 3 p+4$. Namun Subjek 3 hanya menyebutkan bahwa $1=p+4$. Subjek 3 menghadapi kesulitan dengan informasi tersebut hingga akhirnya Subjek 3 mencoba Trial and Error dalam menentukan nilai $\mathrm{p}$ dan 1 . Namun nilai yang dicoba tidak tepat sehingga luas yang didapat tidak benar.

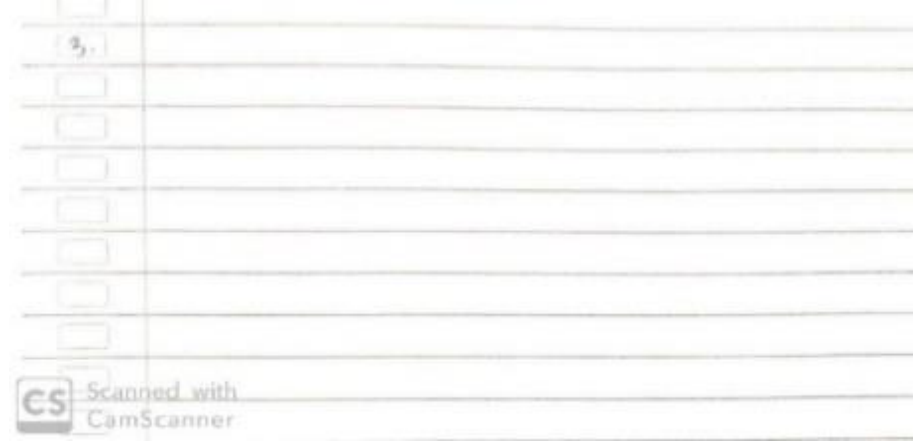

Gambar 9. Jawaban Nomor 3 dari Subjek 3

Gambar di atas adalah gambar jawaban Subjek 3 terhadap soal nomor 2. Adapun wawancara yang dilakukan terkait dengan jawaban yang diberikan sebagai berikut:

P : “.... Terus nomor 3?”

S3 : "Ga ngerti sama sekali" 
P : "Ini padahal soal cerita. Tinggal lihat tabelnya aja. Tentukan $\mathrm{x}$ untuk apa dan y untuk apa nya, lalu tinggal eliminasi atau substitusi, gitu doang! Terus cari yang ditanyakannya apa. Ini kan disuruh menentukan nilai x dan y nya dulu kan? Nah setelah itu hitung biayanya. Misalkan Antum menentukan lahan 1 itu x dan lahan 2 itu y. Nah berarti persamaan pertamanya 300x $+200 y=R p 540.000,00$. Itu yang diketahui. Ya? Berarti baris kedua gimana bentuk matematikanya?"

S3 : "Ga tau Tadz."

P : "Ga tau ya? Coba deh sekali lagi, Jika lahan 1 itu x dan lahan 2 itu y, jadi bentuk matematika dari tahap 2 gimana?"

S3 : "Ehm, 320x + 250y = Rp620.000,00"

P : "Nah misal dari eliminasi dua kali Antum (Kamu) dapat nilai $x$ dan y nya. Sehabis itu ngapain?"

S3 : "Ehm, tambah kali?"

P : "Heem, apa yang ditambah?"

S3 : "Lahan 1 sama lahan 2 nya"

P : "Nah lahan 1 nya?"

S3 : "315"

P : "Jadi, bentuk matematikanya?"

S3 : " $315 x+225 y$ "

P : "Nah setelah dapat nilai $x$ dan y nya, tinggal subtitusikan ke $315 x+225 y$ nanti dapet biayanya berapa, gitu!"

S3 : "Iya Tadz."

Berdasarkan data di atas, dapat disimpulkan bahwa Subjek 3 tidak mendapatkan informasi dari soal tersebut. Hal ini didapat dari gambar di atas yang menunjukkan bahwa subjek tidak menuliskan sama sekali hal yang diketahui dari soal dengan jelas. Alasannya adalah ketika pembahasan materi ini, Subjek 3 tidak menyimak, sehingga Subjek 3 tidak mengetahui cara mencari informasi dari soal tersebut. Subjek 3 tidak menuliskan informasi karena Subjek 3 tidak memahami soal tersebut.

Hasil triangulasi data menunjukkan bahwa subjek tidak bisa sama sekali mendapatkan informasi terkait apa yang diketahui dan apa yang ditanyakan, sehingga penyelesaian tidak bisa dilakukan karena kurangnya pemahaman akan soal tersebut. Subjek tidak bisa memanfaatkan 
waktunya sehingga tidak ada satu pun soal yang tuntas penyelesaiannya. Pada nomor 3, Subjek sama sekali tidak bisa dan tidak mengerti soal.

Pada pembahasan di atas, setiap subjek memaparkan kesulitan-kesulitan yang dialami dalam proses pemecahan masalah. Setiap subjek menghadapi kesulitan yang berbeda dalam pemecahan masalah setiap nomornya. Hal ini terjadi karena jenis soal yang berbeda setiap nomornya.

Subjek 1 memaparkan bahwa pada pemecahan nomor 1, Subjek mengalami kesulitan ketika mengubah kalimat soal menjadi bentuk matematikanya. Hal ini didapat dari kutipan wawancara terhadap Subjek 1. Subjek 1 berkata "Kalo nomor 1 susahnya ngerubah soal ke bentuk matematikanya", walaupun pada akhirnya Subjek 1 bisa memecahkan masalah pada nomor 1 dan menghasilkan jawaban yang tepat. Untuk nomor 2, Subjek 1 memaparkan bahwa kesulitan dialami ketika mengoperasikan pemecahan masalah. Subjek 1 sempat terhambat ketika menghadapi persamaan $16=4 / 3$ p. Namun pada akhirnya Subjek 1 bisa memecahkannya dan mendapatkan nilai p sebesar 12. Untuk nomor 3, Subjek 1 memaparkan bahwa subjek menghadapi kesulitan ketika melihat soal dan perencanaan pemecahan masalah. Ketika ditanya tentang kesulitan karena soal bernominal ratusan ribu, Subjek 1 mengatakan "Iya Tadz. Ehh bukan Tadz, yang ini Tadz. Sempet kekecoh, ternyata enakan pake eliminasi dulu, baru bisa". Dari kutipan tersebut bisa dikatakan bahwa Subjek 1 terkejut terlebih dahulu melihat soal yang menggunakan nominal ratusan ribu. Subjek 1 juga memaparkan sempat terkecoh dalam perencanaan pemecahan masalah. Namun Subjek 1 bisa memecahkan masalah dengan tepat, walaupun dari setiap jawaban Subjek 1 tidak menemukan atau menciptakan konsep baru.

Subjek 2 menghadapi kesulitan di setiap soalnya. Pada gambar 4.27, terlihat bahwa Subjek 2 mengalami kesulitan dalam memperoleh informasi yang ada pada soal. Hal ini dikarenakan catatan hal yang diketahui dan yang ditanyakan yang dimiliki oleh Subjek 2 tidak lengkap dan tidak seluruhnya tepat sehingga jawaban yang dimiliki oleh Subjek 2 tidak tepat. Ketika diwawancara, Subjek 2 menyebutkan bahwa Subjek terkecoh dalam menuliskan informasi dan Subjek hampir lupa terhadap konsep walaupun akhirnya penggunaan konsepnya benar. Hal ini dibuktikan oleh kutipan wawancara berikut: "Nomor 1 mah Ana (Saya) sempet lupa cara nyusunnya. Terus kekecoh sama kalimat " 6 tahun yang akan datang"-lah $\neg$ gitu. Terus angka mana dulu yang mesti disimpen di depan". Subjek 2 mampu menerapkan konsep yang diingat dengan baik, namun Subjek 2 kurang teliti ketika mengoperasikannya sehingga nilai 
variabel yang dihasilkan bernilai salah. Begitupun nomor 2. Subjek kurang teliti dalam membaca soal. Untuk nomor 3, Subjek 2 tidak fokus menyelesaikan karena terkejut melihat nominal bilangannya, namun Subjek 2 menyadari bahwa nominal bilangan bisa disederhanakan. Hal ini dibuktikan oleh kutipan wawancara berikut: "Nomor 3? Angkanya kebanyakan, lupa lanjutan. Bener terkecoh sama banyak nol Ana tuh. Padahal tinggal hilangkan dulu". Karena terkecoh, nilai variabel yang didapat kurang tepat.

Melihat jawaban nomor 1 dan 3 dari Subjek 3, Subjek sama sekali tidak menuliskan apapun di lembar jawaban. Ketika pelaksanaan tes, Subjek 3 pesimis dan ingin segera menyudahi tes tersebut. Dari penjelasan tersebut dapat dikatakan bahwa Subjek 3 memiliki sifat mudah menyerah dan pasrah sebelum mencoba, walaupun pada akhirnya Subjek mulai mengerjakan tes pada soal nomor 2. Untuk nomor 1, sebetulnya Subjek 3 itu paham dengan konsepnya, namun Subjek tidak bisa sama sekali mengubah soal ke dalam bentuk matematikanya karena ketika pembahasan tentang cara mengubah soal ke dalam bentuk matematikanya, Subjek 3 tidak menyimak karena tidur. Hal ini dibuktikan berdasarkan kutipan wawancara berikut: "Pas Ustadz ngejelasin materi ini, Ana (Saya) tidur Tadz. Pas bangun, udah lain lagi pembahasannya. Jadi ketinggalan. Sebetulnya kalo udah dapet mah bisa ngerjain, cuma karena ga bisa nyusunnya jadi aja ga bisa.". Begitupun nomor 3, Subjek 3 mengatakan bahwa Subjek tidak bisa sama sekali mengubah bentuk tabel ke dalam bentuk persamaan biasa. Namun ketika dituntun dan dibimbing, Subjek 3 sedikit-sedikit bisa menuliskan persamaan yang terdapat dalam tabel tersebut. Untuk nomor 2, dilihat pada gambar 4.31, Subjek 3 sudah bisa mendapatkan informasi, dan mengingat konsep yang berkaitan dengan soal. Subjek 3 mendapatkan informasi bahwa persegi panjang pada soal memiliki keliling sebesar $32 \mathrm{~cm}$ dan Subjek 3 mengingat bahwa rumus luas persegi panjang adalah pl (panjang kali lebar). Namun, hal yang belum diketahui pada soal adalah nilai dari p. Dari gambar 4.31, Subjek 3 memecahkan masalah menggunakan Trial and Error, di mana Subjek menentukan secara coba-coba untuk nilai panjang dan lebar, namun ternyata tidak tepat.

Jadi faktor penyebab dari rendahnya kemampuan kognitif pada pemecahan masalah adalah 1) Kurangnya pemahaman tentang materi yang diterapkan pada tes. 2) Lemahnya keterampilan dalam memperoleh informasi dari soal. 3) Kurang teliti dalam pemecahan masalah. 4) Pesimis dan kurang percaya diri. 


\section{KESIMPULAN}

Berdasarkan pembahasan di atas, dapat disimpulkan bahwa siswa dengan tingkat kecerdasan logis-matematis tinggi, memiliki kemampuan kognitif yang tinggi pula pada langkah-langkah pemecahan masalah, namun tidak sampai kepada kategori mencipta (C6) pada tingkatan kemampuan kognitif.

Siswa dengan tingkat kecerdasan logis matematis sedang tidak bisa dikatakan memiliki kemampuan kognitif yang cukup, bahkan masih terbilang rendah, karena siswa tersebut masih belum dikatakan baik pada kemampuan kognitif menerapkan (C3). Hal ini dikarenakan siswa tidak bisa menerapkan konsep atau rumus yang diingat dengan baik.

Siswa dengan tingkat kecerdasan logis matematis rendah memiliki kemampuan kognitif yang rendah. Hal ini dikarenakan siswa tersebut tidak sampai pada tahap memahami (C2). Kecerdasan logis-matematis tidak berbanding lurus dengan kemampuan kognitif. Hal ini terbukti karena siswa dengan tingkat kecerdasan logis-matematis sedang, memiliki kemampuan kognitif yang rendah, bukan sedang. Namun kecerdasan logis-matematis tidak berbanding terbalik dengan kemampuan kognitif, karena siswa dengan kecerdasan logis-matematis tinggi memiliki kemampuan kognitif yang tinggi juga.

Adapun faktor penyebab rendahnya kemampuan kognitif siswa adalah a) Kurangnya pemahaman tentang materi yang diterapkan pada tes. b) Lemahnya keterampilan dalam memperoleh informasi dari soal. c) Kurang teliti dalam pemecahan masalah. d) Pesimis dan kurang percaya diri.

Meningkatkan kemampuan kognitif siswa bisa dilakukan dengan melaksanakan $e$ learning. Menurut Yaniawati, Kartasasmita and Saputra (2019, p. 2), "Utilization of e-learning in mathematics has positive influences. Other than as an effort in solving technical problem as learning media, this can also become an effort to address substantial learning problem as learning material". Artinya adalah pemanfaatan e-learning dalam matematika memiliki pengaruh positif. Selain sebagai upaya memecahkan masalah teknis sebagai media pembelajaran, ini juga bisa menjadi upaya untuk mengatasi masalah pembelajaran yang substansial sebagai bahan pembelajaran. Pengaruh positif e-learning ini bisa meningkatkan kemampuan kognitif siswa. 


\section{REFERENSI}

Ananingsih, S. (2017). Pengaruh Kecerdasan Logis-Matematis terhadap Prestasi Belajar Matematika materi Luas Bangun Data Kelas V di SD Muhammadiyah 09 Malang. Skripsi Sarjana untuk FITK UIN Sultan Malik Ibrahim Malang: tidak diterbitkan.

Fauzi dan Monawati. (2018). "Hubungan antara Kecerdasan Logis-Matematis dan Kedisiplinan

Belajar Siswa kelas V SD Negeri 1 Pagar Air Kabupaten Aceh Besar”, Jurnal Pesona Dasar. 6, (1), 55-62.

Hariyono dan Suryono. (2011). Belajar dan Pembelajaran Teori dan Konsep Dasar. Bandung: PT Remaja Rosdakarya.

Hartono, Y. 2014. Matematika: Strategi Pemecahan Masalah. Yogyakarta: Graha Ilmu.

Hasratuddin. (2014). "Pembelajaran Matematika Sekarang dan yang akan Datang Berbasis Karakter”. Jurnal Didaktik Matematika. 1, (2), 30-42.

Hendriana, H., Rohaeti, E.E., dan Sumarmo, U. (2017). Hard Skills dan Soft Skills Matematik Siswa. Bandung: Refika Aditama.

Marliani, N. 2015. Kemampuan Pemecahan Masalah Matematis pada Mata Kuliah Persamaan Differensial dilihat dari Pembelajaran Konflik Kognitif yang Terintegrasi dengan Soft Skill. Jurnal Formatif. 5, (2), 134-144

Masykur, M.Ag., Fathani, A.H. (2010). Matehamatical Intelligence. Yogyakarta: Ar-Ruzz Media.

Nasution, A.U. dan Asmin. (2017). Perbedaan Kemampuan Pemecahan Masalah Matematis Siswa Menggunakan Model STAD dan Pembelajaran Langsung. Jurnal Inspiratif. 3, (2), 29-36

Puspadewi, K.R. 2012. Pengaruh Model Pembelajaran Ikrar berorientasi Kearifan Lokal dan Kecerdasan Logis Matematis terhadap Kemampuan Pemecahan Masalah Matematika

Putra, H.D. et al. (2018). "Kemampuan Pemecahan Masalah Matematis Siswa pada Materi Bangun Ruang”. Jurnal Ilmiah Pendidikan Matematika. 6, (2), 82-90.

Roikha, M. (2017). Pengaruh Kecerdasan Logis-Matematis dan Kecerdasan Visual-Spasial terhadap Prestasi Belajar Matematika Materi bangun Ruang Kelas V di Sekolah Dasar tamansiswa Turen. Skirpsi Sarjana pada FITK UIN Sultan Malik Ibrahim Malang: tidak diterbitkan.

Sagala, S. (2012) Supervisi Pembelajaran. Bandung: ALFABETA. 
Salamah, U. (2015). Berlogika dengan Matematika 2 untuk Kelas VIII SMP dan MTs. Jakarta: PT Tiga Serangkai Pustaka Mandiri.

Setiadi, D. (2017). Kemampuan Berpikir Logis Matematis Siswa pada Pembelajaran Bangun Ruang dengan menggunakan Strategi Problem Solving di kelas IX SMPN 2 Mataraman Tahun Ajaran 2016/2017. Skripsi Sarjana pada FTK IAIN Antasari Banjarmasin: tidak diterbirkan.

Suciati. et al. (2014) Belajar dan Pembelajaran. Tangerang Selatan: Universitas Terbuka.

Sugiyono. (2016). Metode Penelitian Kuantitatif, Kualitatif, dan R\&D. Bandung: ALFABETA.

Suhendri, H. "Pengaruh Kecerdasan Matematis-Logis dan Kemandirian Belajar terhadap Hasil Belajar Siswa". Jurnal Formatif. 1, (1), 29-39.

Susanti, V.D. (2018). " Analisis Kemampuan Kognitif dalam Pemecahan Masalah Matematis berdasarkan Kecerdasan Logis-Matematis". Jurnal Matematika dan Pendidikan Matematika. 3, (1), 71-83.

Triwinarni, D., Fauzi, dan Monawati (2017). "Pengaruh Kecerdasan Logika Matematika terhadap Kedisiplinan Belajar Siswa Kelas V SD Negeri 1 Pagar Air Kabupaten Aceh Besar”. Jurnal Ilmiah Pendidikan Guru Sekolah Dasar. 2, (1), 16-29.

Ulya, H. (2015). "Hubungan Gaya Kognitif dengan Kemampuan Pemecahan Masalah Siswa”. Jurnal Konseling GUSJIGANG. 1, (2).

Yaniawati, R., P., Kartasasmita, B. G. and Saputra, J. (2019). E-learning assisted problem-based learning for self-regulated learning and mathematical problem solving. Journal of Physics: Conference Series 1280 (4), 042023. DOI: 10.1088/1742$6596 / 1280 / 4 / 042023$ 